\title{
ETHICAL AND LEGAL ISSUES IN MEDICAL TOURISM
}

\author{
Hanis Wahed*
}

\begin{abstract}
In these days, millions of people, especially from developed countries, are travelling to other countries for medical treatment. This development is called 'medical tourism'. Medical tourism is one of the lucrative industries that has expanded rapidly worldwide, including Malaysia. The development is due to factors such as seeking quality medical treatment at lower costs. However, there are certain ethical and legal issues arising from the development of the industry. These issues should be addressed because it may affect the development of medical tourism in the future. Lack of legal recourse and lack of regulation are some examples of legal issues that are discussed in this paper. The ethical issues include the quality of care for treatment provided by medical providers, lack of follow-up care for patients at their home countries, access to care for the local people at destination countries and the issue that arises from the treatment that is illegal in patients' home countries. The objective of this article is to examine these ethical and legal issues in order to assist the growth of the industry and the country's economy in the future. This research is based on analysis of primary and secondary sources such as legislation, textbooks, and journal articles that relates to the medical tourism and issues arising from its development. The article concludes that these ethical and legal issues can be resolved by having a uniform medical tourism regulation.
\end{abstract}

Keywords: medical tourism, ethical and legal issues, lack of legal recourse, quality of care, access to care

Ph.D. Candidate, Ahmad Ibrahim Kulliyyah of Laws, International Islamic University Malaysia email: hanis_wahed@yahoo.com. 


\title{
ISU-ISU ETIKA DAN PERUNDANGAN BERKAITAN PELANCONGAN PERUBATAN
}

\begin{abstract}
ABSTRAK
Pelancongan perubatan merupakan salah satu daripada industri yang pesat membangun dan mampu memberikan pulangan yang besar kepada sesebuah negara. Industri ini mula berkembang luas di kebanyakkan negara termasuk Malaysia. Perkembangan ini disebabkan oleh beberapa faktor termasuk penambahan jumlah pesakit yang pergi ke negara lain bagi mendapatkan rawatan perubatan yang terbaik pada harga yang lebih rendah. Walaubagaimanapun, terdapat beberapa isu berkaitan etika dan perundangan yang timbul akibat daripada perkembangan industri pelancongan perubatan. Isu-isu perundangan adalah seperti kekurangan tindakan perundangan dan kekurangan peraturan. Manakala isu-isu berkaitan etika adalah seperti kualiti perkhidmatan, rawatan susulan, akses kepada perkhidmatan dan rawatan yang tidak dibenarkan. Isu-isu tersebut mampu menggugat perkembangan industri pelancongan perubatan di Malaysia. Objektif makalah ini adalah untuk membincangkan tentang isu-isu tersebut bagi membantu perkembangan industri dan ekonomi negara pada masa akan datang. Perbincangan ini dilakukan melalui analisis sumber-sumber daripada undang-undang, buku teks dan artikel dari jurnal yang berkaitan dengan pelancongan perubatan. Berdasarkan perbincangan yang dibuat, dapatlah disimpulkan bahawa isu-isu etika dan perundangan berkaitan pelancongan perubatan dapat diselesaikan melalui undang-undang yang seragam khusus untuk pelancongan perubatan.
\end{abstract}

Kata Kunci: pelancongan perubatan, isu-isu etika dan perundangan, kekurangan tindakan undang-undang, kekurangan peraturan, kualiti perkhidmatan, akses kepada perkhidmatan 


\section{INTRODUCTION}

The last few years witnessed dramatic development in medical tourism, particularly in Asian countries. This wave of transformation can be seen from the fact that millions of patients, especially from developed countries travelling to places like Malaysia, Thailand and India for medical procedures ranging from plastic surgery to other medical treatment. ${ }^{1}$ Medical tourism has developed due to lower costs in treatment for a greater access to the quality and recognized medical treatment. ${ }^{2}$ There was a study on the factors that promote medical tourism in Malaysia. ${ }^{3}$ The research was conducted at six private hospitals, which hosted most medical tourists in 2010. The result indicated that the main motivation that attracts foreign patients was the low cost of medical treatment. Other factors included excellent medical facilities and cultural and religious similarity.

In Malaysia, medical tourism is expanding rapidly as a lucrative business opportunity. The industry has been identified as one of the twelve initiatives under the National Key Economic Areas to assist Malaysia in becoming a developed country by $2020 .^{4}$ The development is attributable to the efforts made by the government and private sectors, most noticeably in marketing and promoting the industry. Since then, the number of foreign patients travelling to Malaysia for healthcare has risen sharply. This corresponds with the report by the Malaysian Health Care Travel Council (MHTC) on the overall foreign healthcare patients from 2011 until 2014. The statistic

Lunt, N., Smith, R., et all, Medical Tourism: Treatments, Markets and Health System Implications : A Scoping Review (OECD: Directorate for Employment, Labour and Social Affairs, 2011), 7.

2 Horowitz, M. D., Rosensweig, J. A., \& Jones, C. A., "Medical Tourism: Globalization of the Healthcare Marketplace", Medscape General Medicine, vol. 9, no. 4 (2007): 33; Gray HH. Poland SC, "Medical tourism: Crossing borders to access health care," Kennedy Institute of Ethics Journal, vol. 18, no. 2 (2008): 193-201; Ormond, Meghann, "Medical tourism, medical exile: Responding to the cross-border pursuit of healthcare in Malaysia" in Minca, C. and Oakes, T. (eds), Real Tourism: Representation, Practice, Care and Politics in Contemporary Travel, (London: Routledge, 2011),143-161.

3 Musa, G., Thirumoorthi, T., \& Doshi, D. "Travel Behaviour Among Inbound Medical Tourists in Kuala Lumpur," Current Issues in Tourism, vol.15, no. 6 (2012): 525-543.

4 Ormond, "Medical tourism, medical exile," 143-161. 
shows that the number of foreign patients increased from 641,000 in 2011 to 882,000 in $2014 .^{5}$

However, several ethical and legal issues arise from the development of medical tourism. The main focus of the paper is to examine these ethical and legal issues, since these issues can affect the decision of patients in choosing medical tourism. The discussion is divided into five sections, namely: the meaning of medical tourism, the development of medical tourism, legal issues, ethical issues, and conclusion. The first and the second sections are the introductory sections that briefly discuss about medical tourism, especially its development. This is followed by third section that the discusses the legal issues that arise as a result of the development of the industry. The fourth section is a brief discussion on the ethical issues such as quality of care, lack of adequate follow up care access to care and treatments which are illegal in patients' home countries.

\section{THE MEANING OF MEDICAL TOURISM}

Medical tourism (also called medical travel or health tourism) refers to the practice of travelling across international borders to obtain healthcare. ${ }^{6}$ Most writers have given the same interpretation of medical tourism. One of the early interpretations was given by Goodrich \& Goodrich as follows:

... the attempt on the part of a tourist facility (e.g. hotel) or destination (e.g. Baden, Switzerland) to attract tourists by deliberately promoting its health care facilities, in addition to its regular tourist amenities. ${ }^{7}$

Medical tourism has been portrayed as a popular mass culture, which involves patients' international travel to a private hospital to obtain medical care and at the same time enjoying a holiday in the

5 Malaysia Healthcare Travel Council, "Statistics: Comparison of Healthcare Travellers between 2011 - 2014", accessed 15 November 2015, http://www.mhtc.org.my/en/statistics.aspx.

6 "Medical Tourism-What is Medical Tourism", accessed March 3, 2013, www.news-medical.net/health/Medical-Tourism-What-is-Medical-ourism.aspx.

7 Goodrich, J. \& Goodrich, G, "Health-care tourism - An exploratory study," Tourism Management, 8(3) (1987): 217. 
destination country. ${ }^{8}$ The definition includes foreign tourists who travel not for healthcare, but require it during their stay in the destination country. ${ }^{9}$ Carrera and Bridges define medical tourism as, 'The organized travel outside one's natural healthcare jurisdiction for the enhancement or restoration of the individual's health through medical intervention, ${ }^{10}$

\section{THE DEVELOPMENT OF MEDICAL TOURISM}

Travelling abroad for healthcare has its own long history started from the rich and upper social classes who went to spas, mineral baths, and to the Mediterranean countries to improve their health. ${ }^{11}$ For instance, the practice of wealthy Europeans to travel to places like spas and the Nile for treatment was recorded since the seventeenth century. ${ }^{12}$ During that period, medical treatment was not considered as a service which could be traded internationally. Most of the services were offered by health resorts and spas, including services like thermal springs, related health checkups and herbal medicine. ${ }^{13}$

The 'traditional international medical travel' took place at the later part of the $20^{\text {th }}$ century. The traditional international medical travel involved patients from developing countries traveling to

8 Crooks, VA. Turner, L. Cohen, IG. Et al, "Ethical and Legal Implications of the Risks of Medical Tourism for Patients: a Qualitative Study of Canadian Health and Safety Representatives' Perspectives," (2013), BMJ Open, accessed February 27, 2013, http://bmjopen-2012-002302; See also, Cohen, I. G, "How to Regulate Medical Tourism (and why it Matters for Bioethics)," Developing World Bioethics, 12(1) (2012): 9-20; Lunt, Smith, et al, Medical Tourism : Treatments, Markets .....

9 Vinay Kumar Singh, "Public Policies for Facilitating Medical Tourism Industry in Asia," IV Annual International Conference on Public Policy and Management, (Bangalore: IIM, August, 2009).

10 Carrera P, Bridges J, "Globalization and Healthcare: Understanding Health and Medical Tourism," Expert Review of Pharmacoeconomics and Outcomes Research. 6(Suppl 4) (2006): 447-454.

11 Gray and Poland, 193-201.

12 Burkett, L, "Medical Tourism. Concerns, Benefits, and the American Legal Perspective," The Journal of Legal Medicine, 28(2), (2007): 223-245. See also, Porter, R., "The Medical History of Waters and Spas. Introduction", Medical History. Supplement, 10 (1990): 7-12.

13 Becheri, P. E, "From Thermalism to Health Tourism", Tourism Review, 44(4), (1989): at 15-19. See also, Goodrich and Goodrich, "Health-Care Tourism ..." 217-222. 
developed countries for better facilities and advance technologies. ${ }^{14}$ It was said that before 1997, the centre of healthcare was in developed countries, particularly the United States and Europe. ${ }^{15}$ These countries played a very important role in providing the best treatments to patients. In the United States, many renowned hospitals such as the Cleveland and Mayor Clinics provide medical services to foreign patients. ${ }^{16}$ Meanwhile, in Europe, places like London and Austria are famous for their medical competence and well equipped facilities and state of the art technologies. ${ }^{17}$

The recent trend in medical tourism is significantly different from the traditional international medical travel and can be described as patients travelling from developed countries to developing countries in order to avoid treatment delays, to receive affordable quality medical care or simply to have elective surgery combined with sightseeing and other local tourism opportunities. ${ }^{18}$

The newest trend in the first decade of the twenty-first century has the middle class travelling from developed countries to those with emerging economies to avoid treatment delays, prohibitive costs for life saving procedures, or simply high costs for elective surgery. Others leave to have access to assisted suicide in countries that have legalized it. This new era of globalization in healthcare has arrived without the benefit of international standards, government oversight, or ethical and legal review. ${ }^{19}$

14 Horowitz, M. D., \& Rosensweig, J. A., "Medical Tourism vs. Traditional International Medical Travel: A Tale of Two Models" International Medical Travel Journal, (10 September 2008): 1-14; MacReady, N. "Developing Countries Court Medical Tourists." Lancet, vol. 369, no. 9576 (2007): 1849-50.

15 Goodrich, 217-222.

16 See, Mayo Clinic, accessed November 15, 2013, http://www.mayoclinic.org/.

17 Volz, D., "Reverse Medical Tourism", Hospitals and Health Networks, vol. 82, no.6 (2008): 12-14.

18 Gray and Poland, 193-201. See also, Helble, M., "The Movement of Patients Across Borders: Challenges and Opportunities for Public Health", Bulletin of the World Health Organization, 89(1) (2011): 68-72; Milstein, A. "America's New Refugees - $\quad$ Seeking Affordable Surgery Offshore", $N$ Engl J Med, 355 (2006): 1637-1640; York D., "Medical Tourism: The Trend Toward Outsourcing Medical Procedures to Foreign Countries", Journal of Continuing Education in the Health Professions, 28(9) (2008): 99-102.

Gray and Poland, 193-201. 
One of the first countries that experienced the current medical tourism was Cuba. ${ }^{20}$ In the early 1990's, the country promoted sun and surgery packages, which included services like organ transplant and cosmetic procedures. ${ }^{21}$ The Cuban government encouraged the admission of foreign patients as a tool to alleviate its economic crisis, which occurred from 1989 until $1993 .{ }^{22}$

It is not clearly known when and how this current medical tourism started to develop. However, some argued that the Asian financial crisis in 1997 was one of the main factors that triggered the emergence of medical tourism, especially in Southeast Asian countries, including Malaysia, Singapore and Thailand. ${ }^{23}$ These countries were forced to seek alternative strategies to cope with the serious economic downturn. At that time, many private hospitals lost their local patients, while doctors and some medical providers began leaving their countries to work elsewhere. As a result, private hospitals were forced to change strategies by targeting foreign patients. $^{24}$

Another important factor that caused the emergence of medical tourism was the September 11 attacks. The biggest impact was on Muslims who at the time were discouraged to travel to western countries, especially to the United States. Muslims had to face strict procedures before entering the country because of the tightened security and immigration laws, especially for Arabs. Due to that, Muslims, especially from the Middle Eastern countries began to travel to countries like Malaysia, Thailand and Singapore for medical treatment. $^{25}$ For example, prior to September 11, 2001, the Bumrungrad Hospital in Thailand treated fewer than 10,000 patients

20 Smith, K, "Medical Tourism: For Richer or Poorer," Paper presented at Ownership \& Appropriation, a joint conference of the ASA, the ASAANZ and the AAS, 8th - 12th December 2008, University of Auckland, New Zealand, 2. Ibid.

22 Chee, H. L, "Medical tourism and the state in Malaysia and Singapore", Global Social Policy, 10(3) (2010): 336-357.

23 Ibid., 342.

24 Turner L, "First World Health Care at Third World Prices: Globalization, Bioethics and Medical Tourism," BioSocieties, 2(3) (2007): 303-325. See also, Chee, H. L., \& Barraclough, S., Healthcare in Malaysia: The Dynamics of Provision, Financing and Access, (London: Routledge, 2007); Ormond, M., Mun, W. K., \& Khoon, C. C., "Medical tourism in Malaysia: How can we better identify and manage its advantages and disadvantages?" Global Health Action, 7 (2014): 2 .

25 MacReady, "Developing countries", 1849-50. 
annually from the Middle East. By 2003 the number had risen to 22,000 patients annually and in 2010, approximately 125,000 patients from the Middle East were treated at the hospital. ${ }^{26}$

\section{LEGAL ISSUES}

The development of medical tourism leads to several legal issues. First, patients who are travelling abroad for medical treatment may find it difficult to seek justice in cases involving medical malpractice due to the inadequacies of the law in the destination countries. Furthermore, there is lack of uniform regulation that regulates medical tourism. The following sub-sections briefly discuss these legal issues.

\section{Lack of Legal Recourse}

One of the legal issues and the biggest constraint in medical tourism is the lack of legal recourse and accountability for malpractice or unsatisfactory medical treatment given by foreign medical providers. ${ }^{27}$ The opponents of medical tourism have argued that patients who leave their country and receive negligent medical treatment might not be able to obtain legal remedies in the countries where they received the treatment. ${ }^{28}$ The reason is because of the inadequacies in the law that governs the medical malpractice cases in the destination countries. ${ }^{29}$ It is difficult to bring an action for medical malpractice in medical tourism cases due to the different standards and rules that exist in different jurisdictions. This is especially so if the law depends heavily on the evidence obtained

26 Hamdan, S, "Thailand Profits From Health Care to Arab Patients", The New York Times, February 8, 2012, accessed June 25, 2015, www.nytimes.com/2012/02/09/world/middleeast/09iht-m09-gulf-medical.html.

27 Puteri Nemie Jahn Kassim, "Medicine Beyond Borders: The Legal and Ethical Challenges" Medicine and Law, 28 (2009): 445; Puteri Nemie Jahn Kassim, "Cross-Border Issues in the Development of Medical Tourism in Malaysia: Legal Challenges and Opportunities" Journal of Law and Medicine, 17 (2009): 62.

28 Vinay Kumar Singh. See also, Smith, R., Martínez Álvarez, M., \& Chanda, R., "Medical tourism: a review of the literature and analysis of a role for bilateral trade", Health Policy (Amsterdam, Netherlands), 103(2-3) (2011): 278. Puteri Nemie Jahn Kassim, "Medicine Beyond Borders", 446. 
from doctors in deciding the standard of care. ${ }^{30}$ Furthermore, the international litigation can be expensive and difficult to be enforced. ${ }^{31}$

This discourages patients to travel to other countries for medical treatment for fear of the lack of legal recourse and remedies. A survey was conducted to study factors affecting patients in deciding whether or not to opt for medical tourism. ${ }^{32}$ On the issue of having to sue in a foreign country in case of medical malpractice, only $4.9 \%$ responded positively while another $19.5 \%$ stated that they were somewhat concerned about the problem. As a result, the development of the medical tourism industry in the future will be affected. The solution might be in the form of an alternative to the current medical negligence system, such as alternative dispute resolution (ADR).

\section{Lack of Regulation}

There is no uniform law or guideline that specifically protects patients who receive medical treatment outside their countries or provides information on patients' right for legal recourse. ${ }^{33}$ This means that patients are unaware of their rights and ability to sue in cases of medical injuries arising from medical tourism. The position is different in the US, which has its own medical tourism guideline. The Medical Tourism Guideline by the American Medical Association (AMA) provides that patients should be informed of their rights and legal recourse prior to agreeing to travel outside the country. ${ }^{34}$ There is also lack of uniform regulation regarding medical devices and treatment that should be used by medical providers. The consequences may be harmful to patients who opted for medical

30 Cortez, N., "Patients Without Borders: The Emerging Global Market for Patients and the Evolution of Modern Health Care", Indiana Law Journal, 83(1) (2008): 71-132.

31 Storrow, R. F., "Assisted reproduction on treacherous terrain: The legal hazards of cross-border reproductive travel", Reproductive BioMedicine Online, 23(.5) (2011): 540.

32 Medical Tourism Association, (2009), "MTA Releases First Patient Surveys on Medical Tourism" Medical Tourism Magazine (May/June 2009): 34-36.

33 Lunt, Smith, et al, "Medical Tourism: Treatments, Markets".

34 American Medical Association (AMA), Medical Tourism Guideline, 2008, accessed November 16, 2015, http://www.ama-assn.org/ama/home.page; Wapner, J. "American Medical Association provides guidance on medical tourism” BMJ, (2008), accessed November 16, 2015, http://www.bmj.com/content/337/bmj.a575. 
tourism. ${ }^{35}$ For example, the scandal over the Poly Implant Prosthese (PIP) breast implant, where French manufacturers used industrialgrade silicone rather than medical-grade silicone to reduce the costs due to lack of regulations. ${ }^{36}$

The example of the lack of uniform regulation can best be seen in cases involving surrogacy. The law is varied based on different cultures, traditions and religious views of each country. ${ }^{37}$ Some countries legalises surrogacy, while others do not. The differences in legal recognition of surrogacy between countries might create problems for those who opt for the procedure. The problem arises when the prospective parents are from countries that do not legalise surrogacy, namely France, Italy and Spain. In India, the rule is that gay couples, non-married couples, single men and women and couples from countries that illegalised surrogacy are not allowed to hire surrogate mothers in India. ${ }^{38}$ It means that prospective parents from the countries that illegalised surrogacy are not allowed to have surrogate babies. Even if they have, their countries will not recognise the status of the surrogate babies. Denying the legal recognition of the parentage of prospective parents and surrogate babies seems a bit draconian and does not solve the problem that may arise from surrogacy. ${ }^{39}$

In the UK, the laws that govern surrogacy and gamete donation are the Surrogacy Arrangements Act 1985 and Human Fertilisation and Embryology Act 2008 respectively. These laws provide

35 Vick, L., "The Perils of Cosmetic Surgery/Medical Tourism”, Clinical Risk, 18(3) (2012): 109.

36 "PIP Breast Implant - Latest From the NHS", Health News, NHS Choices, June 18, 2012, accessed June 19, 2015, http://www.nhs.uk/news/2012/01January/ Pages/government-review-advises-on-french- pip-breast-implants.aspx. See also, Kim Willsher, "French Breast Implant Firm PIP's Founder Jailed", December 10, 2013, accessed June 19, 2015, http://www.theguardian.com/world/2013/dec/10/french-breast-implant-pip-jeanclaude-mas-jailed.

37 Crockin, S. L., "Growing families in a shrinking world: Legal and ethical challenges in cross-border surrogacy", Reproductive BioMedicine Online, 27(6) (2013): 734. See also, Gurtin-Broadbent, Z., "Problems with Legislating against 'Reproductive Tourism'”, Bionews, March 22, 2010, accessed July 3, 2015, http://www.bionews.org.uk/page_56954.asp.

38 Bhowmick, N., "Why people are Angry about India's New Surrogacy Rules", Time Magazines, February 15, 2013, accessed July 2, 2015, http://world.time.com/2013/02/15/why-people-are-angry- about-indias-newsurrogacy-laws/. Ibid. 
regulations and restrictions, which are different from laws of other countries. For instance, the UK laws do not require adoption of the surrogate baby for legal recognition. On the contrary, the laws in Belgium require an adoption before the surrogate baby is legally recognised and allowed to be in the country. ${ }^{40}$

In Malaysia, there is no specific law that governs reproductive tourism or surrogacy. The only relevant guideline is the one introduced by the Malaysia Medical Association (MMA). ${ }^{41}$ Other laws, such as the Medical Act 1971 and the Human Tissues Act 1974, only state about the rules and regulations of medical practice and do not control the matter relating to surrogacy. ${ }^{42}$ Therefore, a specific law is needed to regulate the procedures and to monitor the development of reproductive tourism, especially surrogacy in Malaysia. In fact, there was a proposal for a new legislation called, the Assisted Reproductive Technique Services Act which was drafted and expected to be completed in 2012. The proposed law will focus on issues relating to surrogacy, egg and sperm donation. ${ }^{43}$ However, until today the proposed law is still not yet enforced. ${ }^{44}$

The lack of regulation affects the development of medical tourism as patients will be reluctant to pursue medical treatment. The reason is fear of not having protection in cases of negligence of medical providers and lack of awareness of their rights as a patient against the medical provider. Therefore, as have been mentioned, there should be a uniform regulation that governs all countries in cases involving medical tourism.

\footnotetext{
40 Crockin, "Growing families", 735.

41 “Assisted reproduction law facing hurdles, says D-G", The Star Online, updated June 2, 2013, accessed July 2, 2015, http://www.thestar.com.my/News/ Nation/2012/10/06/Assisted-reproduction-law-facing-hurdles-says-DG/.

42 Arshat, H., "Ethics in assisted human reproduction", Medical Journal of Malaysia, 44(1) (1989): 1- 2 .

43 Ahmad, N., "An International View of Surgically Assisted Conception and Surrogacy Tourism", Medico-Legal Journal, 79(4) (2011): 141. See also, Ber, R., "Ethical issues in gestational surrogacy", Theoretical Medicine and Bioethics, 21(2) (2000): 160.

44 "Assisted reproduction law facing hurdles."
} 


\section{ETHICAL ISSUES}

Medical tourism has raised several ethical concerns not only affecting the foreign patients and their home countries but also the local people at the destination countries. These include: the quality of care provided by the medical providers at the destination countries, the home countries' burden in treating complications and providing follow-up care to patients who opted for medical tourism, the effects of medical tourism on the local healthcare of the destination countries, and treatment which are illegal in patients home countries.

\section{Quality of Care}

The quality of medical care can be determined by looking at the accreditation of the medical providers. ${ }^{45}$ The Medical Tourism Association survey shows that $80.5 \%$ of patients agreed that accreditation plays a vital role in their decision for travelling to foreign countries. ${ }^{46} 58.5 \%$ of patients stated that hospital accreditation is very important before choosing the hospital. However, the opponents of medical tourism question the quality of care given by medical providers in destination countries. The reasons are because there is no standard grading since the guidelines for accreditation itself differ between countries and the level of medical facilities could vary from one hospital to another. ${ }^{47}$

First, the quality of medical treatment is questionable because the standard by which they are graded are more lenient compared to the accreditation system in developed countries. For example, the American Medical Association (AMA) insists that the quality of treatment in the developing countries is not comparable to what is offered in the United States. ${ }^{48}$ Furthermore, the opponents argued

45 Abdullahel Hadi , "Globalization, medical tourism and health equity", (2009).

This paper is prepared to present at the Symposium on Implications of Medical Tourism for Canadian Health and Health Policy on November 13, 2009 in Ottawa, Canada, 15; Herrick D.M., Medical Tourism: Global Competition in Healthcare, National Center for Policy Analysis. Dallas. TX. Report no. 304. November, 2007, accessed April 29, 2013, http://www.ncpa.org/pub/st/st304.

46 Medical Tourism Association, "MTA Releases First Patient Surveys" 34-36.

47 Abdullahel Hadi, "Globalization, medical tourism", 15.

48 American Medical Association (AMA), accessed November 23, 2013, http://www.ama-assn.org/ama. See also, Lunt, Smith, et al, "Medical Tourism: Treatments, Markets". 
that not all accredited hospitals offer high quality treatment like the Bumrungrad hospital in Thailand. ${ }^{49}$ In fact, some hospitals offer lower quality facilities, which could result in high risks of complications and less protection for foreign patients in case of malpractice. There might be some possibilities for exploitation due to the absence of regulatory safeguards concerning standards, quality, and costs of treatment and lack of recourse in cases of medical negligence. ${ }^{50}$

The solution is to have one accreditation system that is applicable to all countries as a tool to determine the quality of treatment provided by the medical providers. Currently, most of the medical providers in developing countries are accredited, either by the Joint Commission International (JCI), which is the most established medical tourist industry accreditor worldwide or by the International Standard Organization (ISO). Some countries even have adopted their own accreditation standards to reassure potential patients about the quality of medical treatment provided. For example, the regulation in Malaysia is done by the Malaysian Society for Quality in Health (MSQH), a non-government and non-profit organization which aims for quality improvement in healthcare by assessing the performance of medical providers. Similarly, the Indian National Accreditation Board for Hospitals (N.A.B.H) is established as the local accreditation agency for medical providers in India. ${ }^{51}$ This

49 The Bumrungrad Hospital has the outstanding reputation as one of the best hospitals in medical tourism in Thailand. The hospital employs reputed, internationally trained doctors, who are competent to provide a wide range of medical treatment. For more discussion, see Burkett, "Medical Tourism. Concerns, Benefits", 223-45; "Nine Reasons to Make Thailand your Medical Tourism Destination," $\quad$ March 2014, http://www.thailandmedtourism.com/Article/119/0/Nine-Reasons-to- MakeThailand-Your-Medical-Tourism-Destination; Herrick, Medical tourism: global competition in healthcare, 4.

50 Chanda, R., "Trade in Health Services," Bulletin of the World Health Organization, vol.80, no.2 (2002): 158-163.

51 Schroth, L., \& Khawaja, R., "Globalization of healthcare", Frontiers of Health Services Management, vol. 24, no. 2 (2007): 19-30; MSQH-Who are We, accessed February 25, 2014, http://www.msqh.com.my/msqh/ct-menu-item-3/ctmenu-item-5. See also, Dahlui, M. and N. A. Aziz (2012), 'Developing Health Service Hub in ASEAN and Asia Region Country Report on Healthcare Service Industry in Malaysia' in Tullao, T. S. and H. H. Lim (eds.), Developing ASEAN Economic Community (AEC) into A Global Services Hub, 1 (Jakarta: ERIA Research Project Report, 2011): 65-110, 92, accessed June 22, 2015, 
means that there is no uniform standard in determining the quality of care of medical providers. Therefore, it is suggested for a uniform accreditation system that applicable worldwide to govern medical tourism medical providers.

\section{Lack of Adequate Follow-up Care}

While most patients are satisfied with the treatment received, some might suffer from medical complications and infections after returning to their home countries. These might happen due to the low quality of care and standard of the treatment provided by some of the medical tourism providers. Some patients might require follow-up care to monitor the healing process. ${ }^{52}$ According to a survey by the British Association of Plastic, Reconstructive and Aesthetic Surgery, $37 \%$ of its members had seen patients with complications resulting from medical tourism. ${ }^{53}$ Another survey revealed that half of the international travelers suffered health problems, $7 \%$ in need of medical treatment and $1 \%$ need to be hospitalised. ${ }^{54}$

This might be a burden to home countries and local doctors, who have to bear the costs for treatment and correct any negligent act committed by foreign medical providers. ${ }^{55}$ Furthermore, the patient who suffers complication and are unable to sue the foreign provider might later decide to sue the local doctor who provides the follow-up treatment. This is the reason why local doctors might refuse to provide follow up treatment to patients who travel abroad for medical treatment. ${ }^{56}$

http://www.eria.org/Chapter\%202-

Malaysia's\%20Report\%20on\%20Health\%20Services.pdf.

52 Turner, L., "Making Canada a destination for medical tourists: Why Canadian provinces should not try to become "mayo clinics of the north", Healthcare Policy, vol. 7, no. 4 (2012): at 23-24, accessed June 22, 2015, http://www.ncbi.nlm.nih.gov/pmc/articles/PMC3359081/pdf/policy-07-018.pdf.

53 Crooks, Turner, Cohen, et al, "Ethical and legal implications.

54 Chen, L. H., \& Wilson, M. E. "The globalization of healthcare: Implications of medical tourism for the infectious disease clinician", Clinical Infectious Diseases, vol. 57, no.12 (2013): 1753.

55 Herrick, Medical Tourism: Global Competition in Healthcare, 25.

56 Hopkins, L., Labonté, R., Runnels, V., et al, "Medical Tourism Today: What is the State of Existing Knowledge?" Journal of Public Health Policy, vol. 31, no. 2 (2010): 185-198. See also, Ferraretti, A. P., Pennings, G., Gianaroli, L., et al, "Cross-border reproductive care: A phenomenon expressing the controversial 


\section{Access to Care}

Medical tourism may have made positive impact on the destination country, notably its economy. Nevertheless, there are concerns about the negative impact of medical tourism on the local healthcare, including the accessibility of care by the local people. ${ }^{57}$

The increase in medical tourism may have potential negative effects on equity and access to care for the poor and disadvantaged in provider countries, and the safety and quality of care of foreign patients. $^{58}$

Medical tourism has been criticised for creating a two-tier system of healthcare in destination countries. The industry has also broadened the gap between different classes: poor $\mathrm{v}$ rich and between foreign patients $\mathrm{v}$ local patients. ${ }^{59}$ For example, by building impressive high technology private hospitals that provide healthcare for foreign and rich local patients as compared to public hospitals, which are housed in old buildings with outdated equipment for local and lower income patients, leaving them without basic care. ${ }^{60}$

The negative impact is the undesired consequences in terms of accessibility and equity in healthcare due to the comparatively higher cost in the private hospitals as compared to public hospitals. ${ }^{61}$ Due to the higher price chargeable on foreign and higher income patients,

aspects of reproductive technologies", Reproductive BioMedicine Online, vol. 20, no. 2 (2010): 265.

57 Vick, "The perils of cosmetic surgery/medical tourism," 109. See also, Ormond, Mun, and Khoon, "Medical tourism in Malaysia," 1; Arellano, A. R. de, \& Lynch, M., "Patients without Borders: The Emergence of Medical Tourism", International Journal of Health Services, vol. 22, no. 7 (2006): 1-12.

58 Abdullahel Hadi, "Globalization, Medical Tourism" 19.

59 Smith, Martínez Álvarez, and Chanda, "Medical Tourism: a Review of the Literature," 276-282; Lum, M., The Implications of Health Tourism. The Star Online. 15 February 2015, accessed June 28, 2015, http://www.thestar.com.my/Lifestyle/Health/2015/02/15/The-implications-ofhealth-tourism/.

60 Kanchanachitra, C., Lindelow, M., Johnston, T., et all, "Human resources for Health in Southeast Asia: Shortages, Distributional Challenges, and International Trade in Health Services", The Lancet, vol. 377, No. 9767 (2011): at 769-781. See also, Leonard, P., "Will expansion of the NHS abroad benefit UK patients? Yes", BMJ, vol. 346, No. 1 (2013); Herrick, Medical tourism: global competition, 23.

61 Chee, H. L., The Emergence of a Transnational Healthcare Service Industry in Malaysia (No. 76) (2006): 24, accessed March 24, 2013, http://ssm.com/abstract=1317169 
private hospitals tend to focus on these categories of patients rather than local patients with lower income. Local patients with lower income are sometimes being denied access to the best treatment offered in private hospitals because of the exorbitant price of medical treatment. Only those from middle to higher income can afford the expensive medical services in private hospitals. ${ }^{62}$ Consequently, the differential pricing for foreign patients could drive up costs of services for local patients over time and increase the overall cost of medical treatment. ${ }^{63}$

Furthermore, countries using their national resources on care for foreign patients are actually limiting their own citizen's equitable access to care and have indirectly deprived their own native-born poor population. ${ }^{64}$ As discussed earlier, medical tourism has resulted in the construction of large specialised private hospitals mainly for foreign patients without considering the domestic market or the needs of local patients with lower income. ${ }^{65}$ This has distorted the main purpose of the healthcare, which is to provide the best medical treatment to its citizens. The example can be seen in India, where there is very low funding leading to inadequate and unsanitary health facilities in public healthcare. Similarly, in Bangladesh, where there has been a public debate on the implications of opening up health sector to foreign direct investment, which might affect health coverage of the local and lower income patients. ${ }^{66}$

But the proponents of medical tourism argue that the increasing revenue from medical tourism can be used to subsidise and make available treatment to local and lower income patients. ${ }^{67}$ However,

62 Chanda, "Trade in Health Services," 158-163; Pocock, N. S., \& Phua, K. H., "Medical tourism and policy implications for health systems: a conceptual framework from a comparative study of Thailand, Singapore and Malaysia," Globalization and Health, vol. 7, no. 1 (2011): 8.

Herrick, Medical Tourism: Global Competition, 23; Pocock and Phua, "Medical Tourism and Policy implications," 6.

Leahy, A. L., "Medical tourism: the impact of travel to foreign countries for healthcare", The Surgeon: Journal of the Royal Colleges of Surgeons of Edinburgh and Ireland, vol. 6, no. 5 (2008): 260-1.

Vijay NM., Medical Tourism: Subsidizing Healthcare for Developed Countries, (2009), accessed March 14, 2014, http://www.scribd.com/doc/ 11724381/Medical-Tourism-KABANI1.

Chanda, "Trade in Health Services," 158-163.

Turner, "Making Canada a Destination," 18-25. See also, Lunt, Smith, et al, Medical Tourism: Treatments, Markets and Health,; Ormond, Mun, and Khoon, "Medical tourism in Malaysia," 2. 
medical tourism will inevitably divide the healthcare system. Therefore, some appropriate measures are needed to create an opportunity for the local and lower income patients to acquire access to the high quality healthcare that medical tourism could provide. One of the measures is by having specific legal provision to subsidise medical treatment for local and lower income patients. A regulatory framework should be introduced to ensure that the benefits of upgrading healthcare are extended to all patients, such as assigning a certain percentage of the beds in the hospitals to the lower income patients for free or subsidised treatment. ${ }^{68}$

\section{Treatments which are Illegal in Patients' Home Countries}

Medical tourism services can be divided according to its legality as follows: services that are legal in the home and destination countries, namely hip replacement; services that are illegal in the home countries, but legal in the destination countries, such as assisted reproductive treatments (ARTs), and services that are illegal in both countries, such as organ sale. ${ }^{69}$

One important feature of the medical tourism market is the provision of services that are either illegal in many developed countries, not paid for by insurance companies (such as facelifts, hair transplants, dental treatment and liposuction) or which have to go through long legal procedures to get those services (such as surrogacy and organ transplant). ${ }^{70}$

These medical tourism services give rise to several ethical issues, especially in cases involving services which are illegal in some countries. The example is surrogacy, which is a practice where a woman is pregnant and giving birth to a child for someone else. ${ }^{71}$ As have been mentioned, some countries have criminalised surrogacy. However, the practice is legal in some of destination countries. In

68 Blouin C., "Trade in Health Services: Can it Improve Access to Healthcare for Poor People?" Global Social Policy, vol. 10, no. 3 (2010): 293-295.

69 Cohen, I. G., "Protecting Patients with Passports: Medical Tourism and the Patient-Protective Argument", Iowa Law Review, 95 (2010). See also, Cohen, I. G., "Medical Tourism: The View from Ten Thousand Feet," The Hastings Center Report, 40(2) (2010): 11-12.

70 Turner L., "Medical Tourism: Family Medicine and International HealthRelated Travel, Canadian Family Physician, 53(10) (2007): 1639-1641.

71 Humbyrd, C., "Fair trade international surrogacy", Developing World Bioethics, 9(3) (2009): 111. 
2002, India legalised surrogacy in an effort to promote medical tourism. $^{72}$ The practice has raised complicated ethical issues, in particular in relating to informed consent and exploitation of poor and illiterate women.

Informed consent is said to be given after there is a communication of medical risks and benefits to the patient. In surrogacy, the procedure is considered ethical if the surrogate mothers are informed and understand the risks of the procedure. However, surrogate mothers may be in a disadvantaged position owing to the economic and power differential between them and clients. In most cases, surrogate mothers are poor and illiterate women who communicate through third parties. ${ }^{73}$ For example, in India, most surrogate mothers are uneducated village girls who do not understand their rights. ${ }^{74}$ They are paid a fee to be artificially inseminated, housed and monitored in a dorm-like facility for the duration of their pregnancies. $^{75}$ The issues involved are both legal, such as: whether the consent is given freely even if it may be economically coerced and whether it is ethical to encourage surrogacy if the prime factor is for financial need.

\section{CONCLUSION}

The development of medical tourism brings numerous advantages to the people. It gives the opportunity to the people to access quality treatment which is not available in their home countries at a lower cost and permits expedited access to medical treatment. However, the

72 Schanbacher, K., "India's Gestational Surrogacy Market: An Exploitation of Poor, Uneducated Women”, Hastings Women's Law Journal, 1 (2014): 201220. See also, Brenhouse H., "India's Rent-a- Womb Industry Faces New Restrictions", Time Magazine, USA, June 5, 2010, accessed July 1, 2015, http://content.time.com/time/world/article/0,8599,1993665,00.html.

73 Deonandan, R., Green, S., \& van Beinum, A., "Ethical Concerns for Maternal Surrogacy and reproductive tourism", Journal of Medical Ethics, (2012): 742743; Ahmad, N. "An International View",141. See also, Ber, "Ethical issues in gestational surrogacy", 160.

74 Shapiro, A., "Surrogate Parenting: A Worldwide Industry, Lacking Global Rules", June 11, 2015, accessed June 29, 2015, http://www.npr.org/sections/parallels/2015/06/11/413406325/surrogateparenting-a-worldwide-industry-lacking-global-rules.

75 Mulay, S., \& Gibson, E., "Marketing of Assisted Human Reproduction and the Indian State," Development, 49(4) (2006): 84-93. 
expansion of medical tourism raises several ethical and legal issues, which might affects further development of the industry. The article has discussed some of these ethical and legal issues that arise.

The legal issues are lack of legal recourse and regulations that regulate medical tourism. As discussed, the solutions for these issues are to introduce methods of alternative dispute resolution in the existing laws on medical tourism and to establish a uniform regulation that governs countries in cases involving medical tourism. By having the alternative dispute resolution, patients may be able to be compensated without having to endure the cumbersome proceedings in courts. The uniform regulation is needed to assist patients and to give awareness about their rights and ability to sue in cases of medical injuries arising from medical tourism.

Patients' use of medical tourism also raises important ethical issues, ranging from issues about patients' safety and the impact of medical tourism on the patients' home countries and destination countries. First, the quality of care for some treatment provided by medical providers is questionable due to the difference in the standard of determining it. Next, medical treatment and the follow up care that is given after returning home is ethically problematic because the cost of this treatment falls on the home countries of the patient. To make things worse, medical tourism may exacerbate health inequalities for the local poor people at the destination countries. Lastly, the ethical issue that arises from medical tourism is when patients travel for receiving treatment that is illegal in their home countries. The resolution is to have a uniform accreditation system that is responsible to determine the quality of care for all medical providers. A uniform regulatory framework should also be introduced to ensure that the upgrading healthcare is accessible to all patients and to regulate the treatment that is illegal. 